\title{
Effect of Competence, Career Development and Compensation on Organizational Commitments (Case Study on Samsat on Lombok Island)
}

\author{
Sofyan; Surati; Hermanto \\ Master of Management Study Program, Postgraduate University of Mataram, Indonesia \\ http://dx.doi.org/10.18415/ijmmu.v8i2.2340
}

\begin{abstract}
The purpose of this study was to determine the effect of competence, career development and compensation on organizational commitment at the Samsat office on the island of Lombok. This research is a causal associative research. The study population was all 199 employees in Samsat on the island of Lombok. The research sample was 133 respondents. From the number of samples, the number of each sample in each section was determined by stratified random sampling. The main technique used for data collection is to use a questionnaire technique (questionnaire). To determine the magnitude of the influence of the independent variables on the dependent variable, multiple linear analysis was carried out. The $t$ test is used to test the influence of the independent variables, namely job satisfaction, career development and compensation to the dependent variable, namely organizational commitment. Based on the results of the study, it was concluded that: 1) Competence has a positive and significant influence on organizational commitment, meaning that the better the competencies possessed by employees of the SAMSAT office on the island of Lombok, the higher the commitment of these workers to the organization. 2) Career development has a positive and significant impact on organizational commitment. This means that the better the opportunities that employees of the SAMSAT office on the island of Lombok receive in developing their careers, the higher their commitment to the organization. 3) Compensation has a positive and significant effect on organizational commitment. This means that the better the compensation received by the employees of the SAMSAT office on the island of Lombok, the higher their commitment to the organization.
\end{abstract}

Keywords: Competence; Career Development; Compensation; Organizational Commitments

\section{Introduction}

Local Government Organizations are institutions that run the wheels of the Government whose source of legitimacy comes from the community. The community gives trust to government administrators with good performance that must be balanced so that services can be improved effectively and touch the community (Ramandei, 2009). Good governance must have human resources who have sufficient capacity to work and can handle government affairs. Human resources in an organization have an important role, because without the support of good human resources an organization can face problems in achieving organizational goals. The development of an organization is largely determined by 
the individual performance of each member of the organization (Athar, 2020). Creating organizational goals effectively and efficiently in the organization requires good cooperation between members of the organization. Satisfactory and stable employee performance results, of course, are also influenced by good organizational commitment from each employee.

Organizational commitment is an impetus in individuals to do something in order to support the success of the organization with goals and prioritizing organizational interests. An employee who has a high commitment can be involved in the organization because of the similarity of the values he holds with the values of the organization. Organizational commitment becomes an emphasis in the organization because this commitment will determine the attachment of workers to the organization which in turn will determine workers to continue to join and advance the organization or to find other, more promising jobs. Organizational commitment has a significant effect on performance (Athar, 2020). Employees who are committed to the organization are believed to be able to dedicate more time, energy and talents to the organization, compared to employees who are not committed (Tommy \& Julia, 2004).

Crow et al., (2012), said that organizational commitment is the psychological state of an employee which can be seen from the sense of employee loyalty and being able to focus on the goals set by the organization. Meanwhile, according to Steer and Porter (1987) organizational commitment is a person's attitude in identifying himself with the organization, along with the values and goals and the desire to remain a member of the organization to achieve organizational goals. Organizational commitment has an important role for the organization in the operational process. Likewise, organizational commitment has an important role for individual members of an organization to build cooperation, foster morale, and create loyalty to the organization. Organizations that have a high commitment will make the organization more competitive because highly committed employees are usually creative and innovative (Miftahun \& Sugiyanto, 2010). Organizations need qualified employees who have a high level of commitment to be able to survive competitively (Athar, 2020).

Competence describes the knowledge base and performance standards required to successfully complete a job or hold a position. Employee competence is characterized by the extent of employee knowledge, skills, traits, and behavior which can be technical, interpersonal skills related or business oriented. In improving employee performance, adequate competence of the standards set is required. Because competence has a very important role, to be able to do a job. The higher a person's level of competence, the easier it is to accept and develop knowledge and technology, and innovation in work, so that it will increase productivity.

In addition to competence, organizational commitment is influenced by the career development of an individual. Career development is a formal approach that organizations take to ensure that people with the right qualifications and experience are available when needed, because career planning and development benefits both individuals and organizations (Simamora, 2007). According to Siagian (2002), career development is a step taken by companies to face the demands of employee duties and to answer future challenges in developing human resources in the company which is a must and absolutely necessary. On the other hand, a factor that can affect organizational commitment is the compensation given from the organization Mowday (2008).

Werther and Davis in Wibowo (2012) define compensation as what employees receive in exchange for their contribution to the organization, in compensation there is an incentive system that links compensation to performance, whereas according to Rivai (2010), compensation is something that employees receive as a substitute for contributions their services to the company. Meanwhile, according to Mowday (2008), compensation is the total amount of compensation received by employees in lieu of the services they have provided. The general purpose of providing compensation is to attract, retain and motivate employees, the components of compensation consist of financial compensation (direct and 
indirect) and non-financial compensation (satisfaction that a person receives from the job itself or from the psychological and or physical environment in which the person works.). The compensation indicators as stated by Simamora (2007) are wages, incentives, allowances, facilities. Compensation is an important factor that affects how and why employees work in an organization referring to all forms of remuneration for employees that come from completing their work (Mathis and Jackson, 2011).

Compensation has many meanings with the same aims and objectives, namely regarding remuneration, reward, compensation for contributions and rewards in the form of financial and nonfinancial for the work that has been completed. Providing compensation in accordance with the workload, the company has expectations of its employees to show the level of loyalty in advancing the company. Compensation is also an important factor in influencing employee perceptions to work for a company (Athar, 2020).

Several previous studies have been carried out on competence, career development, compensation and organizational commitment as done by Fadli (2012), Rommi (2017), Fakrul (2017) which shows that competence has a positive and significant effect on organizational commitment. Then several previous studies, have examined the effect of career development on organizational commitment. Research conducted by Wibowo (2006), Hidayat (2012) and Nurhidayatul (2017), states that career development has a positive and significant impact on organizational commitment. Meanwhile, research conducted by Sari (2010) and Jaya (2014) found career development did not have a significant effect on organizational commitment. Research conducted by Prabowo et al (2016), shows that compensation has a positive and significant effect on the organizational commitment of nurses and midwives at Bhayangkara Hasta Brata Batu Hospital. While several previous studies were also conducted by Rustini (2015), Suharnomo et al. (2016), Buraidah, (2008), Fatmawati, (2017) and Nurhidayatul (2017) state that compensation has a positive and significant effect on organizational commitment.

One-Stop One-Stop Administration System (SAMSAT) as a system formed to expedite and accelerate services for public interests whose activities are carried out in one office. Human resource development at the SAMSAT office needs to be carried out continuously so that it will produce professional, dedicated, and highly disciplined government employees / apparatus. Human resources play an active and dominant role in every organizational activity, because humans are planners, actors, and determinants of the realization of organizational goals. The SAMSAT Sepulau Lombok office is a Technical Service Unit (UPTB) of the Regional Revenue Management Agency (Bappenda) of West Nusa Tenggara Province (NTB). There are 199 employees at the Samsat office in Lombok, consisting of elements from the NTB Bappenda, Jasa Raharja NTB Branch and the NTB Regional Police Traffic Directorate. Employees at the Samsat Sepulau Lombok office are required to work well and professionally and be full of responsibility.

Based on the results of observations and interviews conducted in Samsat on the island of Lombok, it is true that there are several problems experienced by employees in carrying out their jobs. These problems are usually due to low employee commitment, such as the low level of loyalty, the level of indiscipline service working hours, which can be seen from the presence of lazy employees working in completing reports that should be completed on time, but always delayed from the predetermined time, and not a few people provide he complained about the unsatisfactory service, such as the delivery of information that was not transparent, the service time was long enough, and the conditionality of public services that was not yet conducive. The human resources owned by this agency are not in balance with the amount of work that must be done. With these conditions, of course, more optimal employee competence is needed then service working hours which should be ontime according to the service time notice board always experience delays when starting service, there are still employees who do not apple in the morning and skip work hours. 
Various kinds of training have often been carried out to improve the ability of employees in serving the public to pay Motor Vehicle Tax, including ISO 9001: 2015 Certification, which is to standardize service quality, but what is expected is not in line with expectations. For the issue of compensation in the form of incentives, there is still employee dissatisfaction, because there are gaps between groups that are not considered fair in the distribution of incentives. The level of honesty of some tax collectors is still low, as evidenced by the existence of tax irregularities, even though compensation has been given for the workload that has been done, every time an evaluation is carried out throughout the Samsat, there are still findings of employees who are not committed to the established rules, so that which has direct implications for the achievement of organizational goals. Lack of good communication between employees with one another can lead to differences of opinion among employees. For employee career development, there is still different treatment between one employee and another, there are employees who already have a period of service and are eligible for certain positions but those who have been promoted to rank are still low even though their education is the same. Things like this become a problem in employee career development

Based on the phenomena that occur and from some of the previous theories and research above, the researcher is interested in conducting research on "The Effect of Competence, Career Development and Compensation on Organizational Commitment (Case study on Samsat Island Lombok)".

\section{Method}

The type of research used in this research is causal associative research, which is research that aims to determine the causal relationship between two or more variables (Sugiono, 2017) and this causal relationship can be seen from the influence of competence, career development and compensation or those caused by variables. X on organizational commitment or variable Y (Noor, 2015).

This study used a census method, the study population was all employees in Samsat throughout the island of Lombok, consisting of personnel from the NTB Regional Revenue Management Agency (BAPPENDA), PT. Jasa Raharja and the Traffic Directorate of the Regional Police of the NTB Province, Lombok Island Samsat consist of Mataram Samsat, West Lombok Samsat, North Lombok Samsat, Central Lombok Samsat and East Lombok Samsat. The total population on the island of Lombok is 199 people. Based on the calculation of the Slovin formula, the size of the sample for this study was 133 respondents. From the number of samples of 133 respondents, the number of each sample in each section was determined by stratified random sampling.

The type of data in this research is basically qualitative data that will be quantified, qualitative methods are used to find the hypothesis, while quantitative methods are used to test the hypothesis. Sources of data in this study consisted of 2 sources, namely: 1) Primary data is data that is collected directly by researchers from respondents. 2) Secondary data is data collected from other parties.

In this study, the Samsat documentation for the island of Lombok. Other secondary data are in the form of literature review and previous research. In this study, the main technique used for data collection was the questionnaire technique (questionnaire), while the interview and documentation techniques were used for initial data collection (except for data obtained from documentation citations, research results and literature were used for the purpose of discussing research results).

To find out the magnitude of the influence of the independent variables on the dependent variable, multiple linear analysis was carried out. In this study, the independent variable (independent) is Competence (X1), Career Development (X2), Compensation (X3), while the dependent variable Y is Organizational Commitment. To determine its effect, multiple linear analysis can be used as follows: 


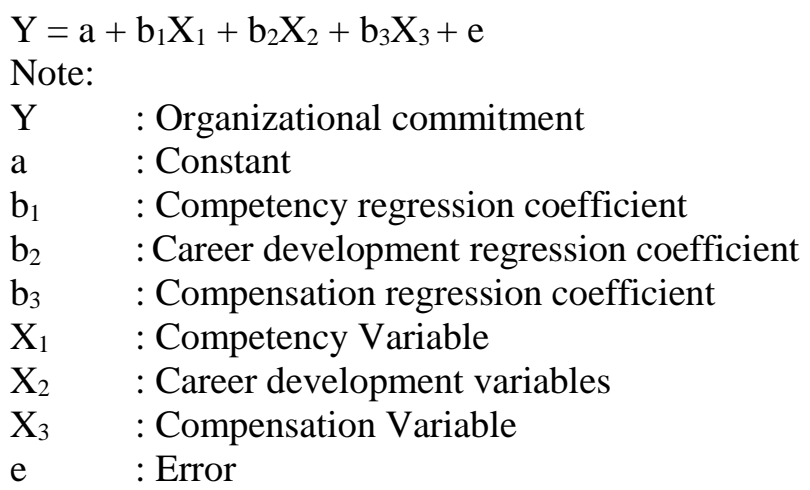

The $t_{\text {test }}$ is used to determine whether each independent variable partially has a significant effect on the dependent variable. This test is done by comparing the calculated $t_{\text {count }}$ with the $t_{\text {table }}$ value. If $t_{\text {count }}>$ $\mathrm{t}_{\text {table }}$ with a significance below $0.05(5 \%)$, then partially or individually the independent variables have a significant effect on the dependent variable, and vice versa. In this study, the $t$ test was used to test the magnitude of the influence of the independent variables, namely job satisfaction, career development and compensation to the dependent variable, namely organizational commitment.

\section{Result and Discussion}

The results of multiple linear regression analysis to predict variations in organizational commitment if influenced by competence, career development, and compensation are presented in Table 1.

Table 1. Value of Multiple Linear Regression Coefficient

\begin{tabular}{|l|l|c|c|c|c|c|}
\hline \multirow{2}{*}{ Model } & \multicolumn{2}{|c|}{$\begin{array}{c}\text { Unstandardized } \\
\text { Coefficients }\end{array}$} & $\begin{array}{c}\text { Standardized } \\
\text { Coefficients }\end{array}$ & & \\
\cline { 2 - 5 } & $\mathrm{B}$ & Std. Error & Beta & $\mathrm{t}$ & Sig. \\
\hline \multirow{2}{*}{1} & (Constant) & 1.831 & 0.659 & & 1.261 & 0.209 \\
\cline { 2 - 7 } & Competence & 0.218 & 0.097 & 0.179 & 2.240 & 0.027 \\
\cline { 2 - 6 } & Career development & 0.167 & 0.119 & 0.114 & 2.405 & 0.042 \\
\cline { 2 - 6 } & Compensation & 0.362 & 0.075 & 0.392 & 4.799 & 0.000 \\
\hline
\end{tabular}

Based on the results of multiple regression analysis in table 1, it is known that the constant value is 0.831 , the regression coefficient value for the competency variable is 0.218 , the career development coefficient value is 0.167 , and the compensation regression coefficient value is 0.362 then, the multiple regression equation is as follows:

$$
\mathrm{Y}=0.831+0.362 \mathrm{X}_{1}+0.167 \mathrm{X}_{2}+0.218 \mathrm{X}_{3}+\mathrm{e}
$$
as follows:

The model equation obtained from the results of the multiple regression analysis can be explained

1. The constant value is 0.831 . This means that the amount of organizational commitment is 0.831 with the assumption that the independent variable value is 0 (zero)

2. The regression coefficient value of the compensation variable is 0.362 . This means that any changes that occur in the compensation variable will cause a change of 0.362 in organizational commitment, assuming the other independent variables are fixed. The regression coefficient which is positive shows a unidirectional relationship between the compensation variable and 
organizational commitment, so the better the compensation is given, the higher the commitment of the employees of the SAMSAT office on the island of Lombok.

3. The regression coefficient value of the career development variable is 0.167 . This means that any changes that occur in the career development variable will cause a change of 0.167 in organizational commitment, assuming the other independent variables are constant. The regression coefficient which is positive shows a unidirectional relationship between the variables of career development and organizational commitment, so that the better the opportunities for employees to develop their careers in the SAMSAT office environment, the higher the commitment of the employees of the SAMSAT office on the island of Lombok.

4. The regression coefficient value of the job satisfaction variable is 0.218 . This means that any changes that occur in the job satisfaction variable will cause a change of 0.218 in organizational commitment, assuming the other independent variables remain. The regression coefficient which is positive shows a unidirectional relationship between the variables of job satisfaction and organizational commitment, so the better the job satisfaction of the employees of the SAMSAT office, the higher the commitment of the employees of the SAMSAT office on the island of Lombok.

Proof of the hypotheses that have been compiled is done by using regression calculations with the help of the SPSS version 17.0 for windows program. The direction and strength of the relationship between the independent variable and the dependent variable turn over intention in this study can be seen from the t-count value and its significance level, as presented in Table 1. The results of multiple regression calculations to prove the hypotheses that have been compiled as shown in the data in Table 1 can be explained as follows:

1. By using the $95 \%$ confidence level, where $\alpha=5 \%$, df (degree of freedom) $=\mathrm{n}-1-\mathrm{k}=133-1-4=$ 128 , so the result for $t$ table is 1.99 . So because $t$ count competency $>t$ table $(2.24>1.99)$ it can be concluded that there is a significant influence of competence on organizational commitment. The significance value of the work environment variable is 0.027 where this significance value is smaller than the predetermined significance value of $5 \%(0.05)$, so it can be concluded that job satisfaction has a positive and significant effect on work commitment of SAMSAT employees on Lombok Island.

2. By using the $95 \%$ confidence level, where $\alpha=5 \%$, df (degree of freedom) $=n-1-k=133-1-4=$ 128 , so the result for $t$ table is 1.99 . So, because $t$ count self-efficacy> t table (2.405>-1.99), it can be concluded that there is a significant effect of career development on organizational commitment. The significance value of the career development variable is 0.042 where this significance value is smaller than the predetermined significance value of 5\% (0.05), so it can be concluded that career development has a positive and significant effect on work commitment of SAMSAT employees on Lombok Island.

3. By using the $95 \%$ confidence level, where $\alpha=5 \%$, df (degree of freedom) $=n-1-k=133-1-4=$ 95 , the result for $t$ table is 1.99 . So, because $t$ count of compensation $t>t$ table (4.799>1.99) it can be concluded that there is a significant effect of compensation on organizational commitment. The significance value of the compensation variable is 0,000 , where the significance value is smaller than the predetermined significance value of 5\% (0.05), so it can be concluded that compensation has a positive and significant effect on organizational commitment. 
Based on the results of the hypothesis testing analysis above, a summary can be made as in table 2 .

Table 2. Summary of Hypothesis Testing

\begin{tabular}{|c|l|c|c|}
\hline No & \multicolumn{1}{|c|}{ Hypothesis } & Significance & Decision \\
\hline 1 & $\begin{array}{l}\text { Competence affects organizational commitment at the } \\
\text { SAMSAT office on the island of Lombok }\end{array}$ & 0.027 & Accepted \\
\hline 2 & $\begin{array}{l}\text { Career development has a significant effect on organizational } \\
\text { commitment at the SAMSAT office on the island of Lombok }\end{array}$ & 0.042 & Accepted \\
\hline 3 & $\begin{array}{l}\text { Compensation has a significant effect on organizational } \\
\text { commitment at the SAMSAT office on the island of Lombok }\end{array}$ & 0.000 & Accepted \\
\hline
\end{tabular}

The coefficient of determination (R2) in essence measures how far the model's ability to explain variations in the dependent variable (Kuncoro, 2007). The determination test (aggregate, R2) is a test of the ability of all $\mathrm{X}$ variables to explain the behavior of variable $\mathrm{Y}$. The results of the calculation of the coefficient of determination (R2) for work environment variables, self-efficacy, work family conflict, employee engagement on turnover intention in this study are presented in Table 3:

Table 3.Determination Coefficient Test Results (R2)

\begin{tabular}{|c|c|c|c|c|}
\hline Model & R & R Square & Adjusted R Square & Std. Error of the Estimate \\
\hline 1 & 0.445 & 0.698 & 0.679 & 0.27457 \\
\hline
\end{tabular}

Table 3 shows that the value of Adjusted R Square (coefficient of determination) is 0.679 (67.9\%). This means that the effect of the three independent variables, namely competence (X1), career development (X2), compensation (X3) on the dependent variable, namely organizational commitment (Y) is $67.9 \%$, while $32.1 \%(100 \%-67.9 \%)$ is influenced by other variables outside this model. Several other variables that affect organizational commitment such as job stress and burn out. To see how all the independent variables influence the dependent variable, namely organizational commitment (Y). Or to prove that the regression model in this study is significant is presented in Table 4.

Tabel 4. Anova results

\begin{tabular}{|c|c|c|c|c|c|c|}
\hline & & $\begin{array}{l}\text { Sum of } \\
\text { Squares }\end{array}$ & df & Mean Square & $\mathrm{F}$ & Sig. \\
\hline \multirow[t]{3}{*}{1} & Regression & 2,396 & 3 & \multirow{3}{*}{$\begin{array}{l}, 799 \\
075\end{array}$} & \multirow[t]{3}{*}{10,594} & \multirow[t]{3}{*}{, $000^{\mathrm{b}}$} \\
\hline & Residual & 9,725 & 129 & & & \\
\hline & Total & 12,121 & 132 & & & \\
\hline
\end{tabular}

In table 4 it can be seen that the calculated $\mathrm{F}$ value is 10.594 with a significance of 0.000 . By using the $95 \%$ confidence level, where $\alpha=5 \%$, df $(\mathrm{k}-1) ; \mathrm{k}(\mathrm{n}-1)=\mathrm{df}(3 ; 132)$, the result for $\mathrm{F}$ table is 2.67. So because the value of $F$ count $>F$ table $(10.594>2.67)$ with a significance level below 0.005 , namely 0.000 . This means that the competency (X1), career development (X2), and compensation (X3) variables together have a significant effect on organizational commitment $(\mathrm{Y})$, or it can be said that the regression model in this study is significant.

Based on the results of the analysis, it is known that competence has a positive and significant effect on organizational commitment, so that hypothesis 1, which states that "Competence has an influence on organizational commitment of employees of SAMSAT throughout Lombok" can be accepted. 
Competence is the nature and characteristics needed by office holders to be able to carry out their duties properly (Athar, 2020). Competence is very important because it can be used to predict employee performance in the future, because competence is a sustainable characteristic and generally cannot be lost (Setiadi, 2016). Good competence will bring greater responsibility for the results of their work, so that they have more desire to be able to provide better results, where this desire is a component of organizational commitment (Athar, 2020).

Based on the results of the analysis, it is known that career development has a positive and significant effect on organizational commitment, so hypothesis 2 which states "career development has an influence on organizational commitment of SAMSAT employees in Lombok Island" is accepted.

In the process, career development can help employees to encourage the growth and development of skills, as well as giving a clear picture of the direction and goals in a career workers. These gains can then increase self-esteem, adaptability and willingness to cooperate on the employees, which is actually the components that make up the workers' commitment to their work. With a positive perception of career development in the company it will tend to encourage increased performance, satisfaction and motivation at work, which then supports the performance and willingness of workers to achieve organizational goals.

Based on the analysis, it is known that compensation has a significant positive relationship with organizational commitment at the SAMSAT office throughout Lombok. Therefore, hypothesis 3 which states that "Compensation has an influence on organizational commitment in the SAMSAT office throughout Lombok" can be accepted.

The results of these findings are in line with several other studies such as that conducted by Alamelu, et. al. (2015) in India, Kee, et. al. (2016) conducted at a banking institution in Malaysia, Nawab and Bhatti (2011) at a Pakistani educational institution, and Paik, et. al. (2007) in 10 companies engaged in the export sector. Regardless of the country background and the field of business, all of these studies show a positive and significant relationship between compensation and organizational commitment. Therefore, it can be said that compensation is an important factor in shaping organizational commitment.

This happens because basically employees work to receive compensation in accordance with expectations and workload. When workers feel that they receive fair compensation according to their workload, a worker will form a commitment to their work (Pratama, et. Al., 2016).

\section{Conclusion}

Based on the results of the analysis and discussion, it is concluded that: 1) Competence has a positive and significant influence on organizational commitment, meaning that the better the competencies possessed by employees of the SAMSAT office on the island of Lombok, the higher the commitment of these workers to the organization. 2) Career development has a positive and significant impact on organizational commitment. This means that the better the opportunities that employees of the SAMSAT office on the island of Lombok receive in developing their careers, the higher their commitment to the organization. 3) Compensation has a positive and significant effect on organizational commitment. This means that the better the compensation received by the employees of the SAMSAT office on the island of Lombok, the higher their commitment to the organization.

\section{References}

Alamelu, R., Surulivel, S. T., Motha, L. C. S., Amudha, R., Selvabaskar, S. 2015. Corralates of Employee Compensation and Commitment. Mediterranean Journal of Social Sciences. Vol. 6, No. 5. 335-341. 
Athar, H. S. (2020). Dampak Gaya Kepemimpinan, Komitmen Organisasi, Dan Kepuasan Kerja Terhadap Kinerja Pegawai Pada Dinas Sosial Kabupaten Lombok Timur. Jurnal Riset Manajemen Dan Bisnis (JRMB) Fakultas Ekonomi UNIAT, 5(2), 29-40. Retrieved from http://jrmb.ejournalfeuniat.net/index.php/JRMB/article/view/402

Athar, H. S. (2020). The Influence of Organizational Culture on Organizational Commitment Post Pandemic Covid-19. International Journal of Multicultural and Multireligious Understanding, 7(5), 148-157.

Buraidah. 2008. Pengaruh Kompensasi Dan Motivasi Kerja Terhadap Komitmen Organisasi Di Organisasi Pendidikan Islam X. Jurnal Manajemen Pascasarjana Psikologi Universitas Gunadarma

Crow, M. S., Lee, C., \& Joo, J. (2012). Organizational justice and organizational commitment among South Korean police officers. Policing: An International Journal of Police Strategies \& Management, 35(2), 402-423.

Diansyah, M., Athar, H. S., \& Fauzi, A. (2020). Kompetensi Dan Komitmen Organisasi Kaitanya Pada Motivasi Dan Kinerja Pegawai. Jurnal Distribusi, 8(2), 267-276. doi: https://doi.org/10.29303/distribusi.v8i2.141

Fadli, Uus, Md. dkk.2012. Pengaruh Kompetensi Karyawan Terhadap Kerja pada PT PLN (persero) Rayon Rengas Dengklok. Jurnal Manajemen. Vol. 09 No.2

Fakrul, R. Y., (2017), Pengaruh Kompensasi dan Kompetensi Terhadap Komitmen Organisasi Serta Implikasinya Pada Kinerja Tenaga Ahli Perusahaan Jasa Konstruksi Di Provinsi Jambi. Jurnal of Economics and Business Vol.1 No.1 September 2017.

Fatmawati. 2017. Analisis pengaruh Kompensasi, Beban Kerja Dan Stres Kerja Terhadap Komitmen Organisasional (Studi Pada Tenaga Pemasar Mikro PT. Bank Rakyat Indonesia (Persero) TBK, Cabang Praya). Jurnal Manajemen Pascasarjana Universitas Mataram. Volume 6, No. 1, Maret.

Hidayat, Syarif Agi. 2012. Pengaruh Kompensasi Dan Pengembangan Karir Terhadap Komitmen Organisasi. Tesis: Universitas Pendidikan Indonesia.

Jaya, Rendra Kusuma. 2014. Pengaruh Pengembangan Karir Dan Konflik PeranTerhadap Komitmen Organisasi Pegawai Sekretariat Daerah Kabupaten Kerinci Dengan Kepuasan Kerja Sebagai Variabel Intervening.Jurnal Manajemen Pascasarjana Universitas Bung Hatta.

Kee, L. B., Ahmad, R. B., Abdullah, S. M. 2016. Relationship between Finansial Compensation and Organizational Commitment among Malaysian Bank Workers. Asian Business Research. Vol. 1, No.1. 75-85.

Mathis, R. L. dan Jackson, H. (2011). Human Resource Management: Manajemen Sumber Daya Manusia. Jakarta: Salemba Empat.

Miftahun dan Sugiyanto. (2010). Pengaruh dukungan social dan kepemimpinan transformasional terhadap komitmen organisasi dengan mediator motivasi kerja. Jurnal psikologi volume 37, No. 1, 94 - 109.

Mowday, R. T., Porter, L. W., \& Steeras, R. (1982). Organizational Linkages: The Psychology of Commitment, Absenteeism, and Turnover. San Diego, California: Academic Press.

Nawab, S. dan Bhatti, K. K. 2011. Influence of Employee Compensation on Organizational Commitment and Job Satisfaction: A Case Study of Educational Sector of Pakistan. International Journal of Business and Social Science. Vol. 2, No. 8. 25-32.

Noor, J., (2015), Metodologi Penelitian. Jakarta: Prenada media Group

Nurhidayatul, P., (2017), Pengaruh Stres Kerja, Kompensasi, dan Pengembangan Karir Terhadap Komitmen Organisasional Perawat Di Rumah Sakit jiwa Mutiara Sukma Mataram Provinsi NTB. Jurnal Magister Manajemen Universitas Mataram.

Paik, Y., Parboteeah, K. P., Shim, W. 2007. The Relationship Between Perceived Compensation, Organizational Commitment and Job Satisfaction: The Case of Mexican Workers in the Korean Maquiladoras. International Journal of Human Resource Management. Vol. 18, No. 10. 1768-1781.

Prabowo, A., Alamsyah, A., \& Noermijati (2016). Pengaruh Kompensasi dan Kepuasan terhadap Komitmen Organisasional Perawat dan Bidan Kontrak di RS Bhayangkara Hasta Brata Batu Malang. Jurnal Aplikasi Manajemen(JAM). I14(1), 58-67. 
Pratama E. W., Musadieq, M. A., Mayowan, Y. 2016. Pengaruh Kompensasi dan Kepuasan Kerja terhadap Komitmen Organisasional (Studi pada Karyawan KSP Sumber Dana Mandiri Gresik). Jurnal Administrasi Bisnis. Vol. 34, No. 1. 1-9.

Ramandei, P. (2009). "Pengaruh Karakteristik Sasaran Anggaran Dan Sistem Pengendalian Intern Terhadap Kinerja Manajerial Aparat Pemerintah Daerah”. Tesis, Program Pasca Sarjana Magister Akuntansi, Universitas Diponegoro Semarang.

Rivai, V., (2010), Manajemen Sumber Daya Manusia untuk Perusahaan Jakarta: PT. Raja Grafindo Persada.

Rommi, J., (2019), Pengaruh Kompetensi, Budaya Organisasi, dan Iklim Organisasi terhadap Komitmen Pegawai Rumah Sakit Umum Bireuen Midical Center (BMC). Jurnal Kebangsaan, Vol.8 No.16 Juli-Desember 2019, ISSN: 2089-5917.

Rustini. Ayu Ni Komang. 2015. Pengaruh Kompensasi Dan Lingkungan Kerja Pada Komitmen Organisasi Dan Implikasinya Pada Kinerja Pengelola.

Sari, Wenny Aqwaresa. 2010. Pengaruh Faktor-Faktor Yang Berkaitan Dengan Karir Terhadap Komitmen Organisasi. Jurnal Manajemen Pascasarjana Universitas Muhammadiyah Surakarta. Vulume 11, No. 2, Desember. Pp. 116-126.

Setiadi, A., Endah W.H.S \& Taufiq, M. (2016). Analisis Komunikasi Dan Kompetensi Terhadap Komitmen Organisasi Dengan Pengembangan Karir Sebagai Vaiabel Moderasi (Studi Kasus Pada Akademi Kepolisian). Dharma Ekonomi. 44(XXIII) Oktober.

Siagian, Sondang P., (2002), Kiat Meningkatian Produktifitas Kerja, Cetakan Pertama, Jakarta: PT. Rineka Cipta.

Simamora, (2007), Manajemen Sumber Daya Manusia.Yogyakarta: STIE YKPN

Steer, Richard M and L W Porter, (1987). Motivation and Work Behaviour. Fourth Edition. New York. Mc Graw Hill.

Sugiyono, (2017), Metode Penelitian Kuantitatif, Kualitatif dan R\&D.Bandung: Alfabeta

Suharnomo. Djastuti, Indi dan Kambey, Fendy Levy. 2016. Pengaruh Budaya Organisasi, Gaya Kepemimpinan Transformasional dan Sistem Kompensasi Terhadap Komitmen Organisasional Dengan Kepuasan Kerja Sebagai Variabel Mediasi. Jurnal Manajemen Pascasarjana Diponegoro

Tommy dan Julia. (2004). Sikap terhadap budaya organisasi dan komitmen organisasi. Jurnal Psikologi Vol. 2 No. 1.

Wibowo, (2012), Manajemen Kinerja.Jakarta : PT Rajagrafindo Persada.

Wibowo, Dewi Felicia. 2006. Analisis Pengaruh Peran Kepemimpinan Dan Pengembangan Karir Terhadap Komitmen Organisasi Dalam Meningkatkan Kinerja Karyawan. Studi Kasus: PT. Bank Maspion Indonesia Cabang Semarang. Tesis: Universitas Diponegoro.

\section{Copyrights}

Copyright for this article is retained by the author(s), with first publication rights granted to the journal.

This is an open-access article distributed under the terms and conditions of the Creative Commons Attribution license (http://creativecommons.org/licenses/by/4.0/). 